\title{
CONDITION OF WATER RESOURCE IN INDONESIA AND ITS ENVIRONMENTAL TECHNOLOGY
}

\author{
By : \\ Kardono \\ Center of Environmental Technology \\ Agency for the Assessment and Application of Technology (BPPT)
}

\begin{abstract}
Water resource is one of the most important resources for life and development. In Indonesia, the increasing population and development results the increased demand of water. On the other hand, water resource availability has become limited and has been at critical level for several locations. Around 65\% Indonesian population ( 125 Million people) live in Java island which is only $7 \%$ of total Indonesia continental area. The decrease of water resource is caused by some factors, namely pollution, deforestation, heavy agricultural activities, and the change of the function of catchment area. This paper will give some brief description how water resource in Indonesia distributes and what the appropriate technologies have been used for the treatment of low quality of water in order to fulfill the human life needs.
\end{abstract}

Keywords: water resource, pollution, climate change, health impact.

\section{INTRODUCTION}

As an island country, Indonesia is vulnerable to climate change. At present, the occurrences of extreme climate events have caused serious impact in many sectors, including clean water resource availability. Indonesia has taken into serious attention to that sector. How the government could adapt or cope with such events in order to lower the impact of the climate change is one of the main government policies. Many programs have been implemented but most of them tend practically more to curative than to preventive actions. Also, better adaptive capacity has not been developed yet and therefore it needs to develop planning horizon, which are: (a) how far should it be projected into the future risk on water supply?; (b) for how long does the impact of the climate change associated with a water resource and supply last?, and (c) when should the new policy be introduced to mitigate the possible impact of incoming climate change?

In terms of health impact, WHO said that 2 (two) billion people have diarrhea and other stomach diseases due to the water and food they consume. These diseases mainly cause death of more than 5 million children annually. Water resources that are already in limited capacity are polluted with industrial waste that is not treated properly before discharging into water body. If it is not radically changed in managing water, it cannot be used anymore without employing a very intensive and expensive technology for water purification which most countries cannot afford it.

Even though the water resource is becoming scarcity, its consumption has increased twice in the last 50 years. At the same time the gap of water consumption between people of the rich countries and those of the poor countries is very high. Nowadays, about 1.2 billion world's population do not have an access to the clean water and almost twice of those numbers do not have proper basic sanitation facilities.

\section{WATER RESOURCE IN INDONESIA}

Currently, water resource potency and availability in Indonesia is around $15,000 \mathrm{~m}^{3}$ per capita per year. It is much higher than the average global water supply of only $8,000 \mathrm{~m}^{3}$ per capita per year. Java island in 1930 was still able to supply around $4,700 \mathrm{~m}^{3}$ water per capita per year, and at present it supplies only one-third $\left(1,500 \mathrm{~m}^{3}\right.$ water per capita per year) of that amount. In year 2020 total potency of water supply in Java island will decrease to $1,200 \mathrm{~m}^{3}$ per capita per year. From this amount of the potential water, only $35 \%$ is economically feasible to be treated as clean water supply so its actual potency is only $400 \mathrm{~m}^{3}$ per capita per year. It is far much lower the minimum requirement suggested by the United Nations that is $1,000 \mathrm{~m}^{3}$ per capita per year. Therefore in 2025, International Water Institute reported that Java and other islands of Indonesia are considered to be as water crisis regions. 
According to Water Resources Development report (1990), Java experienced water supply deficit. Of 66,336 Million $\mathrm{m}^{3}$ required, only 43,952 Million $\mathrm{m}^{3}$ was supplied in 1990. Joko Pitono (2003) also reported that during 1993 dry season, as many as $75 \%$ of Java area experienced water deficit and would have increased the following years. The office of Ministry of Environment (1977) on the other hand predicted that water supply deficit had not occurred yet in Indonesia, except for islands of Java, Bali (started in 2000) and Sulawesi and East Nusa Tenggara (starting in 2015).

It is classical reason that the high number of population is the main cause of the water supply deficit. The land conversion from agricultural and forest land to other forms of uses has been increasing, so that the water resource has been decreasing. In average, about 50,000 hectares of agricultural land is converted into non-agricultural lands yearly. Degradation of watershed area has been increasing from year to year. Land use change from agriculture to nonagriculture causes in decreasing forestry area, increasing in intensity of land utilization, and decreasing in soil and water conservation. Such conditions intensively increase the degradation of natural resources and environment and finally cause the natural disasters such as flood, drought, pollution, eutrophication and sedimentation.

Water resource is divided into surface water (lake, situ, dam/reservoir, river), ground water, and precipitation/rain. Principle of water management follows these principles of continuity, balancing, public advantage, unity, harmony, justice, autonomy, as well as transparency and accountability. River area is defined as river location in one District/City, interDistricts/Cities, inter-Provinces, inter-states, and national strategic river area. Ground water basin includes ground water in one District/City, interDistricts/Cities, inter-Provinces, inter-States, and national strategic river area.

Water resource conservation is aimed to preserve the continuous existence of support capacity, reservoir capacity, and function of water resource. Water resource conservation is carried out through activities of water resource protection and continuity, water preservation, as well as water quality management and water pollution control that follow the design of water resource management determined for each river basin/area. Criteria of water resource conservation become reference in space planning.

The potency of Indonesian surface water is 1.789 billion $\mathrm{m}^{3}$ per year, located in Papua $\left(1.401 \times 10^{9} \mathrm{~m}^{3}\right.$ per year), Kalimantan $\left(557 \times 10^{9}\right.$ $\mathrm{m}^{3}$ per year), Java $\left(118 \times 10^{9} \mathrm{~m}^{3}\right.$ per year).
Surface water scatters in the river (5.886 units), and lake, dam, wetland (33 million hectares).

Around 64 of total 470 watersheds in Indonesia are in critical condition. Of 64 those critical watersheds are 12 areas in Sumatera, 26 areas in Java , 10 areas in Kalimantan, 10 areas in Sulawesi, 4 areas in Bali, NTB and NTT, 4 areas in Maluku, and 2 areas in Papua.

The water flow rate of many rivers in Java highly fluctuates between rainy and dry seasons. Table 1 shows the flow rate of rivers in 2004 and 2005 measured at the rainy season (maximum value) and at the dry season (minimum value). For example, in Citarum river of West Java where water power generation takes place the water flow rate during rainy season (maximum) is around $240 \mathrm{~m} 3 / \mathrm{s}$ whereas during dry season (minimum) is only around $10 \mathrm{~m}^{3} / \mathrm{s}$. In outside Java, the river water flow rate does not very much fluctuate between rainy and dry seasons. For example for Babak river in Lombok island, the water flow rate during rainy season is 587 $\mathrm{m}^{3} / \mathrm{s}$ and it is till $274 \mathrm{~m}^{3} / \mathrm{s}$ during dry season. The reason is that the land use and land use change in outside Java island are still moderate whereas in Java is already very intensive.

\section{WATER POLLUTION}

Water resources are utilized by people for variety of purposes, such as for transportation, for generating electricity, for industrial need, and for tourism. Water and culture are always connected each other. At this present time for example, three big cities of Java (Jakarta, Semarang and Surabaya) have tended to be polluted by wastes from industries, domestics, and agricultures. These wastes have indicated serious water pollution on the environment because they are discharged into the rivers and oceans without any proper treatment.

Domestic waste from business offices and households also contribute significantly for these water pollutions. The amount of the waste discharged into the water body has increased as a function of increasing population and development of the cities. These bad environmental conditions are increased due to very low participation of the people to manage their waste. They often just throw away their waste into the river without any guilty feeling. Therefore, the water pollution has been becoming higher and higher, particularly in big cities of Indonesia. Very dense population and bad sanitation in some cities in Indonesia as well as industrial waste discharged directly into water body without prior treatment have caused pollution in most rivers in those cities.

Waste water from big cities of Indonesia, particularly Jakarta can basically be categorized 
into three groups: (i) industrial waste, (ii) domestic waste from households, and (iii) commercial waste. In addition to pollution of industrial waste the pollution of domestic waste has indicated serious problem. In Jakarta for example, as a result of minimum available waste water treatment, all the waters including the one prepared for drinking water has been highly polluted. A survey done by Public Work Department of Jakarta and JICA (1989), reported that the average household water waste produced per capita per day is $118 \mathrm{~L}$ with BOD content of $236 \mathrm{mg}$ per L. In year of 2010 it is predicted to increase to $147 \mathrm{~L}$ of waste.

Table 1: Flow rate of several rivers in Indonesia ( 2004 and 2005).

\begin{tabular}{|l|l|l|c|c|c|c|}
\hline No & Name of River & Provinsi & \multicolumn{2}{|c|}{ Q 2004 } & $\left(\mathrm{m}^{3} / \mathrm{s}\right)$ & \multicolumn{2}{c|}{ Q 2005 $\left(\mathrm{m}^{3} / \mathrm{s}\right)$} \\
\cline { 3 - 7 } & & Maximum & Minimum & Maximum & Minimum \\
\hline 1 & Citarum Hulu & West Java & - & - & 240 & 10 \\
2 & Way Sekampung & Lampung & 70 & 10 & 130 & 5 \\
3 & Cimanuk & West Java & 1,000 & 4 & 1,000 & 4 \\
4 & Ciliwung & West Java & - & - & 570 & 4 \\
5 & Sungai Bekasi & West Java & - & - & 775 & 5 \\
6 & Cisadane & West Java & - & - & 1,600 & 9 \\
7 & Citanduy & West Java & - & - & 1,757 & 4 \\
8 & Serayu & Central Java & - & - & 2,400 & 25 \\
9 & Keduang & Central Java & - & - & 380 & 0.2 \\
10 & Jeneberang & South & 1,200 & 10 & 1,200 & 10 \\
11 & Jambu & Sulawesi & 260.62 & 104.25 & 265.8 & 78.19 \\
12 & Diiwu Kabah & Sumbawa & 758 & 303.2 & 773 & 227.4 \\
13 & Parado & Sumbawa & 1470 & 588 & 1499 & 441 \\
14 & Tiu Kulit & Sumbawa & 1027 & 410.8 & 1,047 & 308.1 \\
15 & Babak & Sumbawa & 577.25 & 276.72 & 587 & 273.95 \\
16 & Meninting & Lombok & 430.91 & 170.81 & 440 & 169.1 \\
17 & Jangkok & Lombok & 162.15 & 166.49 & 471 & 164.82 \\
18 & Dodokan & Lombok & 134.5 & 188.88 & 443.2 & 187 \\
19 & Penujak & Lombok & 367.61 & 125.88 & 375 & 124.62 \\
20 & Tanggik & Lombok & 184.96 & 87.57 & 189 & 86.69 \\
21 & Pelangan & Lombok & 254.36 & 111.87 & 256.9 & 110.75 \\
22 & Kelep & Lombok & 220.79 & 105.71 & 223 & 105 \\
23 & Sambala & Lombok & 152.4 & 7 & 155.45 & 6.93 \\
24 & Blanting & Lombok & 198.9 & 9.2 & 202.9 & 9 \\
25 & Beburung & Lombok & 266.66 & 168.43 & 268.33 & 166.75 \\
26 & Gereneng & Lombok & 233.87 & 93.29 & 236.21 & 92.36 \\
27 & Koangan & Lombok & 194.4 & 80.89 & 196.34 & 80 \\
28 & Embar-embar & Lombok & 165.76 & 64.62 & 167.42 & 63.97 \\
29 & Amor-amor & Lombok & 205.25 & 88.64 & 207.33 & 87.76 \\
30 & Lak & Lombok & 165.46 & 66.57 & 167.11 & 66 \\
31 & Lempenge & Lombok & 261.56 & 122.21 & 264.35 & 120 \\
& & Lombok & & & & \\
\hline
\end{tabular}

Source: Directorate General of Water Resource, Department of Public Work (2005)

\section{WATER POLLUTION}

Water resources are utilized by people for variety of purposes, such as for transportation, for generating electricity, for industrial need, and for tourism. Water and culture are always connected each other. At this present time for example, three big cities of Java (Jakarta, Semarang and Surabaya) have tended to be polluted by wastes from industries, domestics, and agricultures. These wastes have indicated serious water pollution on the environment because they are discharged into the rivers and oceans without any proper treatment. Domestic waste from business offices and households also contribute significantly for these water pollutions. The amount of the waste discharged into the water body has increased as a function of increasing population and development of the cities. These bad environmental conditions are increased due to very low participation of the people to manage their waste. They often just throw away their waste into the river without any guilty feeling. Therefore, the water pollution has becoming higher and higher, particularly in big cities of Indonesia. Very dense population and 
bad sanitation in some cities in Indonesia as well as industrial waste discharged directly into water body without prior treatment have caused pollution in most rivers in those cities.

Waste water from big cities of Indonesia, particularly Jakarta can basically be categorized into three groups: (i) industrial waste, (ii) domestic waste from households, and (iii) commercial waste. In addition to pollution of industrial waste the pollution of domestic waste has indicated serious problem. In Jakarta for example, as a result of minimum available waste water treatment, all the waters including the one prepared for drinking water has been highly polluted. A survey done by Public Work Department of Jakarta and JICA (1989), reported that the average household water waste produced per capita per day is $118 \mathrm{~L}$ with BOD content of $236 \mathrm{mg}$ per L. In year of 2010 it is predicted to increase to $147 \mathrm{~L}$ of waste.

In Jakarta alone the total waste water is about 1,316,113 $\mathrm{m}^{3}$ per day consisting of domestic waste water $\left(1,038,205 \mathrm{~m}^{3}\right.$ per day), office and commercial waste water $\left(448,933 \mathrm{~m}^{3}\right.$ per day), and industrial waste water $\left(105,437 \mathrm{~m}^{3}\right.$ per day). For Jakarta, from a view point of the total amount, waste water from household, office and commercial, and industry contribute to water pollution of $75 \%, 15 \%$, and $10 \%$; respectively. From an organic loading view point, the contribution of water pollution is coming first from household $(70 \%)$, then from industry $(16 \%)$, and finally from offices and commercials (14\%). Thus, waste water from offices and households cause the main significant impact on the water body. Description of water quality due to domestic waste in Jakarta is shown in Table 2.

Table 2. Characteristics of commercial and domestic liquid waste.

\begin{tabular}{|c|c|c|c|c|}
\hline No & Parameter & Minimum & Maximum & Average \\
\hline 1 & $\mathrm{BOD}-\mathrm{mg} / \mathrm{l}$ & 31,52 & 675,33 & 353,43 \\
\hline 2 & COD - mg/l & 46,62 & 1183,4 & 615,01 \\
\hline 3 & $\begin{array}{l}\text { Permanganate }\left(\mathrm{KMnO}_{4}\right)- \\
\mathrm{mg} / \mathrm{l}\end{array}$ & 69,84 & 739,56 & 404,7 \\
\hline 4 & Ammonia $\left(\mathrm{NH}_{3}\right)-\mathrm{mg} / \mathrm{l}$ & 10,79 & 158,73 & 84,76 \\
\hline 5 & Nitrite $\left(\mathrm{NO}_{2}{ }^{-}\right)-\mathrm{mg} / \mathrm{l}$ & 0,013 & 0,274 & 0,1435 \\
\hline 6 & Nitrate $\left(\mathrm{NO}_{3}{ }^{-}\right)-\mathrm{mg} / \mathrm{l}$ & 2,25 & 8,91 & 5,58 \\
\hline 7 & Chloride $\left(\mathrm{Cl}^{-}\right)-\mathrm{mg} / \mathrm{l}$ & 29,74 & 103,73 & 66,735 \\
\hline 8 & Sulfate $\left(\mathrm{SO}_{4}^{-}\right)-\mathrm{mg} / \mathrm{l}$ & 81,3 & 120,6 & 100,96 \\
\hline 9 & $\mathrm{pH}$ & 4,92 & 8,99 & 6,96 \\
\hline 10 & $\begin{array}{l}\text { Suspended Solid (SS) - } \\
\mathrm{mg} / \mathrm{l}\end{array}$ & 27,5 & 211 & 119,25 \\
\hline 11 & Detergent (MBAS) - mg/l & 1,66 & 9,79 & 5,725 \\
\hline 12 & Oil - mg/l & 1 & 125 & 63 \\
\hline 13 & Cadmium (Cd) - mg/l & ttd & 0,016 & 0,008 \\
\hline 14 & Lead $(\mathrm{Pb})-\mathrm{mg} / \mathrm{l}$ & 0,002 & 0,04 & 0,021 \\
\hline 15 & Coper $(\mathrm{Cu})-\mathrm{mg} / \mathrm{l}$ & $\mathrm{ttd}$ & 0,49 & 0,245 \\
\hline 16 & Iron $(\mathrm{Fe})-\mathrm{mg} / \mathrm{l}$ & 0,19 & 70 & 35,1 \\
\hline 17 & Color - (Scale Pt-Co) & 31 & 150 & 76 \\
\hline 18 & Phenol - mg/l & 0,04 & 0,63 & 0,335 \\
\hline
\end{tabular}

River water quality in Indonesia is mostly affected by domestic waste as well as industrial and agricultural waste. River water monitoring has been done in 30 provinces in 2004, with samples taken twice per year. The monitoring results indicate that parameters of DO, BOD, COD, Fecal Coliforms and Total Coliforms are mostly above the water quality standards class I under Government Decree No. 82 Year 2001.
Percentage for some water parameters monitored at 30 rivers in 2005 is presented in Figure 1.

For biological parameters especially Fecal Coliforms and Total Coliforms indicate that most rivers in populated areas such as in Java are in very critical conditions. The examples are Progo River (Central Java), Ciliwung (Jakarta), and Citarum (West Java). 


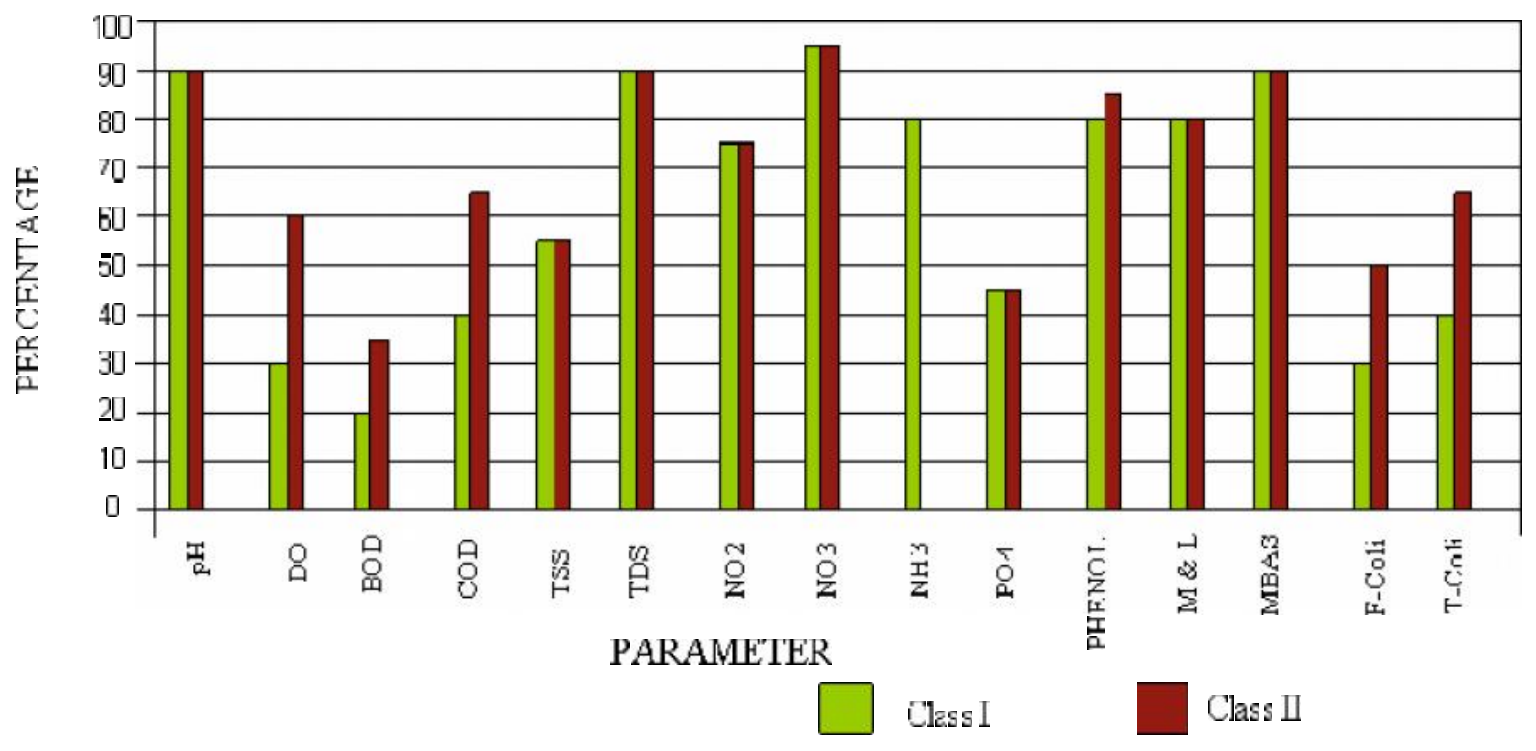

Figure 1: Percentage of some water parameters monitored at 30 rivers in 2005, meeting the water quality standard for Class I and Class II, as stipulated by the Government Regulation No. 82/2001. Note:

Class I water : the water that can be used as raw water to be processed for drinking water, or similar use of such kinds. Class II water: the water that can be used as water recreation, fish culture, animal husbandry, and irrigation or similar use of such kinds.

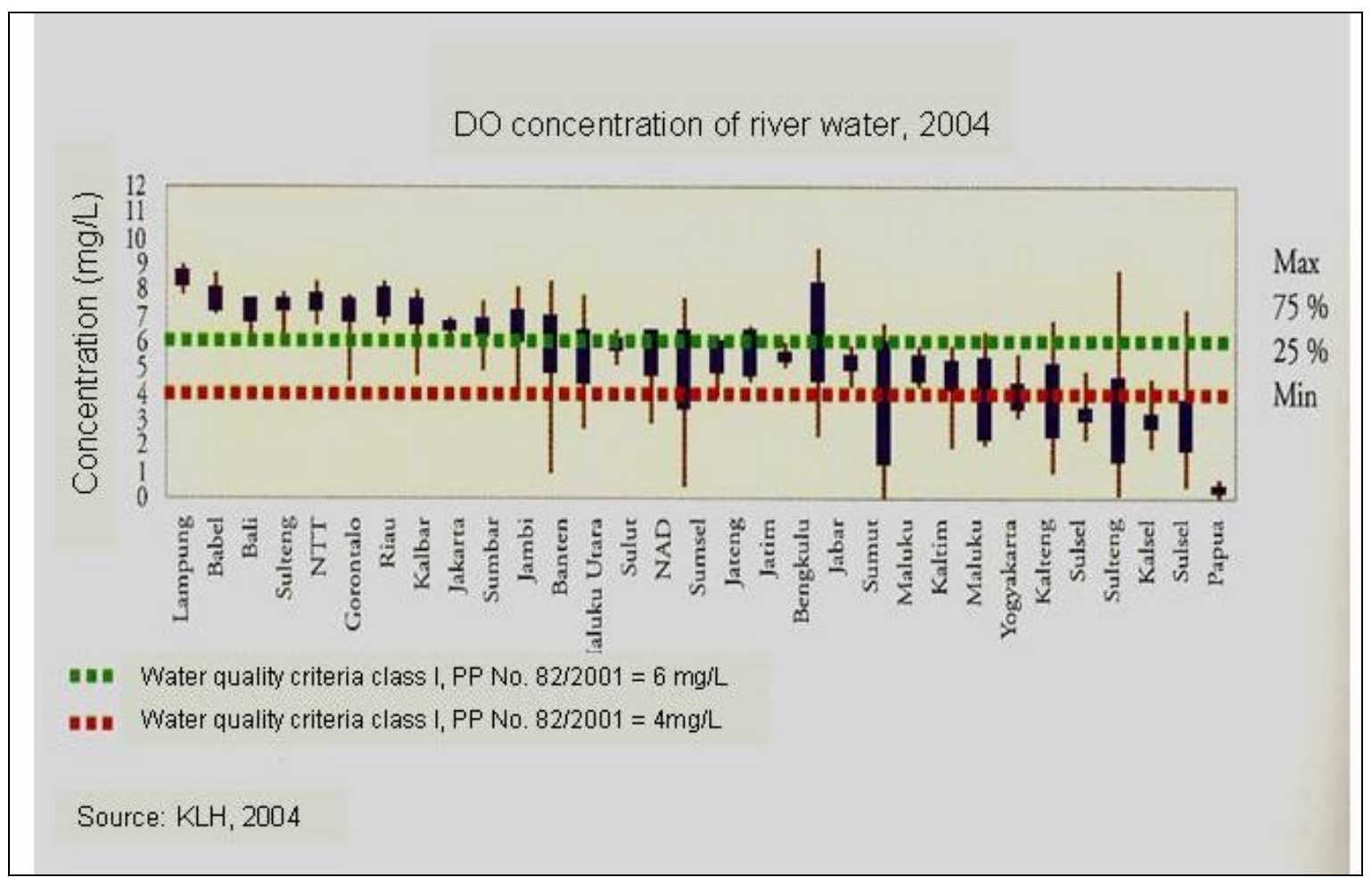

Figure 2. Concentration of dissolved oxygen (DO) of river water in several Provinces (2004). 
Table 2. Status of river water quality of 32 rivers in Indonesia.

\begin{tabular}{|c|c|c|c|}
\hline \multirow[t]{2}{*}{ Province } & \multirow[t]{2}{*}{ River Name } & \multicolumn{2}{|c|}{ Water Quality Status } \\
\hline & & Up-stream & Down-stream \\
\hline NAD & Krueng Tamiang & Light polluted & Meeting the standard \\
\hline North Sumatera & Deli & Light polluted & Light polluted \\
\hline Riau & Kampar & Light to med. Polluted & Medium polluted \\
\hline West Sumatera & Batang Agam & Light polluted & Medium polluted \\
\hline Jambi & Batang Hari & Medium polluted & Light to med. polluted \\
\hline Bengkulu & Air Bengkulu & Light polluted & Light polluted \\
\hline South Sumatera & Musi & Light polluted & Light polluted \\
\hline Lampung & Way Sekampung & Light polluted & Light to med. polluted \\
\hline Babel & Rangkul & Medium polluted & Light polluted \\
\hline Banten & Kali Angke & Light to med. polluted & Light polluted \\
\hline West Java-Banten & Cisadane & Heavy polluted & Medium polluted \\
\hline DKI Jakarta & Ciliwung & Heavy polluted & Heavy polluted \\
\hline West Java & Citarum & Medium polluted & Medium polluted \\
\hline Central Java \& DIY & Progo & Light polluted & Medium polluted \\
\hline East Java & Brantas & Medium polluted & - \\
\hline Bali & Tukad Badung & Light polluted & Light polluted \\
\hline East Nusa Tenggara & Kali Dendeng & Meeting the standard & Light polluted \\
\hline West Nusa Tenggara & Kali Jangkok & Light polluted & Medium polluted \\
\hline West Kalimantan & Kapuas & Light polluted & Light polluted \\
\hline Central Kalimantan & Kahayan & Light to heavy polluted & Light to med. polluted \\
\hline South Kalimantan & Matapura & Light to med. polluted & Light to med. polluted \\
\hline East Kalimantan & Mahakam & Light polluted & Light polluted \\
\hline North Sulawesi & Tondano & Light polluted & Light polluted \\
\hline Gorontalo & Bone & Light polluted & Light polluted \\
\hline Central Sulawesi & Palu & Medium polluted & Light to med. polluted \\
\hline South Sulawesi & Talio & Medium polluted & Light polluted \\
\hline & Jeneberang & Light polluted & Light polluted \\
\hline South-east Sulawesi & Konaweha & Light polluted & Light polluted \\
\hline Maluku & Batu Gajah & Light polluted & Medium polluted \\
\hline & Batu Merah & Light polluted & Medium polluted \\
\hline North Maluku & Tabobo & Medium polluted & Meeting the standard \\
\hline Papua & Anafre & Light polluted & Medium polluted \\
\hline
\end{tabular}

Source:MOE, 2004.

Note: Calculation of water quality status used Pollution Index according to the Ministry of Environment Decree No. 115/2003. Upstream and down-stream water quality values are compared with the water quality criteria class II according to PP No. 82/2001, based on 2 times of monitoring.

More than $98 \%$ of all water is ground water and the rest of $2 \%$ is in river, lake and reservoir. One half of this $2 \%$ is in artificial reservoir. Monitoring to 48 wells was done in Jakarta in 2004 and indicated that most of wells has contained Coliforms and Fecal Coliforms bacteria. Iron (Fe) concentration in ground water of Jakarta has been increasing which some wells contain iron above the standard. Percentage of Jakarta wells containing Mangaan (Mn) above the standard was around $27 \%$ in June 2005 and increased to $33 \%$ in October 2005.

Generally, well water is yellow and slightly smelly. Only around 400 of 4,000 industries in Jakarta install waste water treatment plant. There is no sanitation system in Jakarta so the waste water flows directly into river, and only $2 \%$ of waste water of Jakarta is treated in WWTP. Only $39 \%$ of people of Jakarta have septic tank, and $20 \%$ of them use pit latrines.

\section{WASTE WATER AND WATER TREATMENT}

The types of technology used for waste water treatment and water purification depend on waste water and water characteristic. Table 3 shows the typical technologies and its processes of waste water treatment whereas Table 4 shows typical technologies and its process of water purification implemented by the Center of 
Environmental Technology, the Agency for the Assessment and Application of Technology (BPPT).

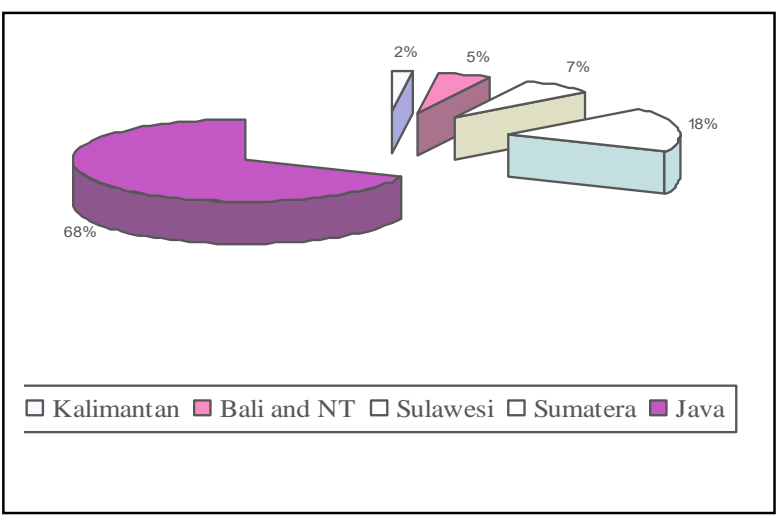

Figure 3. Percentage of households using ground water as drinking water in different islands of Indonesia (2002).

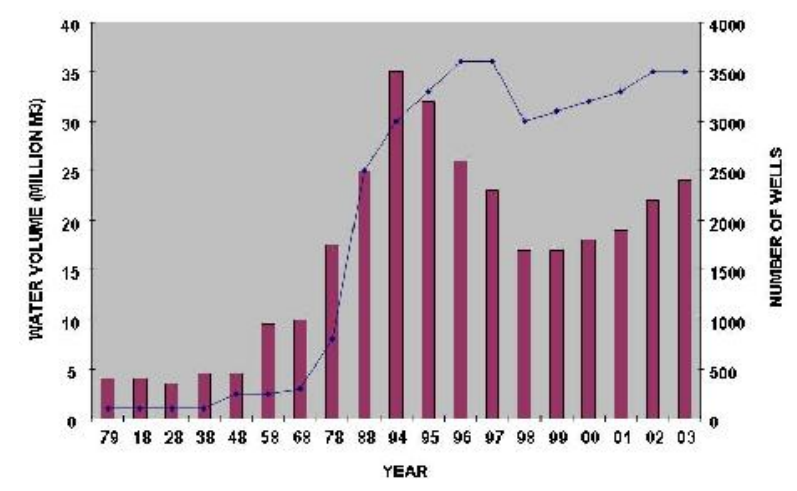

Figure 4 : Number of wells and ground water uptake.

Most of those technologies have been implemented by the Center to treat different types of waste water in Indonesia. The most current one is advanced oxidation processes (AOPs) which is employed to treat specific industrial waste water. AOP is a process of waste water using strong oxidant such as ozone $\left(\mathrm{O}_{3}\right)$ and hydrogen peroxide $\left(\mathrm{H}_{2} \mathrm{O}_{2}\right)$. The benefit of using AOP is that it has ability to degrade strong organic pollutants including oil compounds which is not able to be degraded by common biological processes. It is also used to degrade toxic organic pollutant such as aromatic compounds. Dye pollutant that is difficult to synthesize, such as long chain organic dye (Azo dyes) could be reduced by AOP.

The following Figures 5 through 8 show some examples of experimental reactors of water purification assessed by the Center.

Table 3. Recent waste water treatment technologies implemented by the Center.

\begin{tabular}{|c|c|c|c|}
\hline $\begin{array}{l}\text { Wastewater Pollutant } \\
\text { Characteristic }\end{array}$ & $\begin{array}{l}\text { Type of technology } \\
\text { process }\end{array}$ & \multicolumn{2}{|l|}{ Typical technology } \\
\hline Degradable organic & Biological process & $\begin{array}{ll}\text { Suspended culture } \\
\text { - } & \text { Activated sludge } \\
\text { - } & \text { Oxidation ditch } \\
\text { - } & \text { Separation } \\
\text { - } & \text { Lagoon } \\
\text { - } & \text { UASB (Upflow } \\
& \text { Anaerobic Sludge } \\
& \text { Blanket) } \\
\text { - } & \text { Etc. }\end{array}$ & $\begin{array}{l}\text { Attached culture } \\
\text { - Trickling filter } \\
\text { - RBC (rotating Bio Contactor) } \\
\text { - Biofilter } \\
\text { - Etc. }\end{array}$ \\
\hline Inorganic & $\begin{array}{l}\text { Physical and chemical } \\
\text { processes }\end{array}$ & \multicolumn{2}{|c|}{$\begin{array}{l}\text { - } \text { Coagulation, flocculation and sedimentation } \\
\text { - Absorption and adsorption } \\
\text { - Oxidation process }\end{array}$} \\
\hline $\begin{array}{l}\text { Specific organic and } \\
\text { inorganic: } \\
\text { - Azo dyes } \\
\text { - Nitrate with low organic } \\
\text { content }\end{array}$ & Specific treatment & \multicolumn{2}{|c|}{$\begin{array}{l}\text { - AOPs (advanced oxidation process) } \\
\text { - Denitrification }\end{array}$} \\
\hline
\end{tabular}


Table 4. Recent water purification technologies

\begin{tabular}{|l|l|l|}
\hline $\begin{array}{c}\text { Water } \\
\text { Charac- } \\
\text { teristic }\end{array}$ & $\begin{array}{l}\text { Type of technology } \\
\text { process }\end{array}$ & Typical technology \\
\hline $\begin{array}{l}\text { Fresh } \\
\text { Water }\end{array}$ & $\begin{array}{l}\text { Physical, chemical } \\
\text { and biological } \\
\text { treatment }\end{array}$ & $\begin{array}{l}\text { - Filtration (sand filter, ultra-filtration) } \\
\text { - Coagulation, flocculation, sedimentation. } \\
\text { - Adsorption - absorption (activated carbon) } \\
\text { - lon exchange (demineralization, cation -anion } \\
\text { exchange. } \\
\text { - Biofiltration. } \\
\text { - Fresh water reverse osmosis. } \\
\text { - Etc. }\end{array}$ \\
\hline $\begin{array}{l}\text { Brackish } \\
\text { Water }\end{array}$ & $\begin{array}{l}\text { Physical and } \\
\text { chemical process }\end{array}$ & $\begin{array}{l}\text { - Filtration (sand filter, ultra-filtration) } \\
\text { - Coagulation, flocculation, sedimentation. } \\
\text { - Adsorption - absorption (activated carbon) } \\
\text { - lon exchange (demineralization, cation -anion } \\
\text { exchange. }\end{array}$ \\
& & $\begin{array}{l}\text { - Brackish water reverse osmosis. } \\
\text { - Etc. }\end{array}$ \\
\hline $\begin{array}{l}\text { Sea } \\
\text { Water }\end{array}$ & $\begin{array}{l}\text { Desalination } \\
\text { process }\end{array}$ & $\begin{array}{l}\text { Destillion } \\
\text { Electrodialysis }\end{array}$ \\
& & Reverse osmosis \\
\hline
\end{tabular}

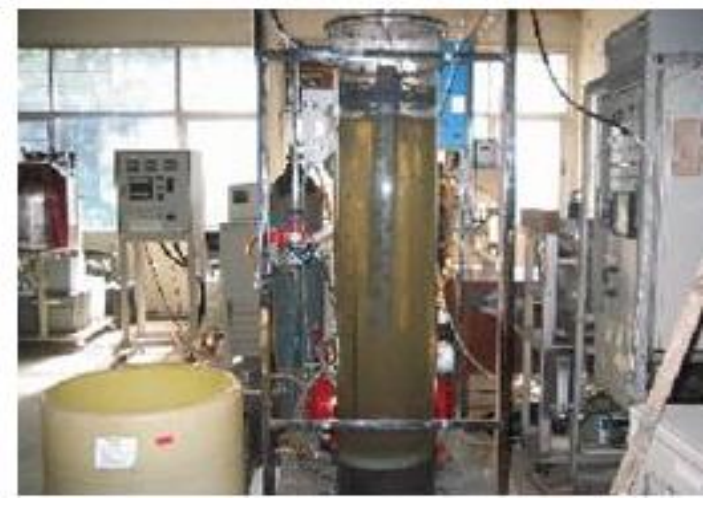

Figure 5. AOP reactor designed by the Center.
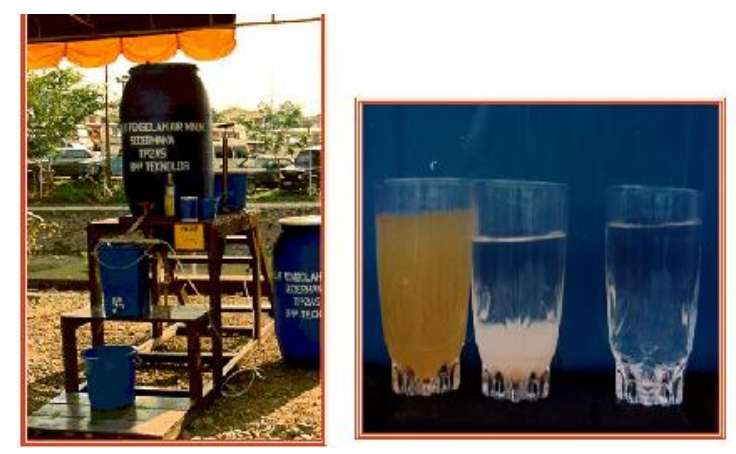

Figure 6. An example of simple water purification reactor.

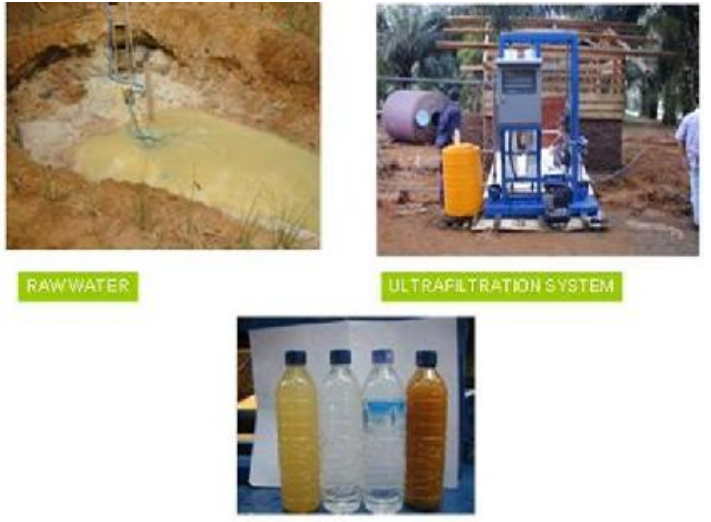

Figure 7. An example of membrane ultrafiltration of water purification reactor.

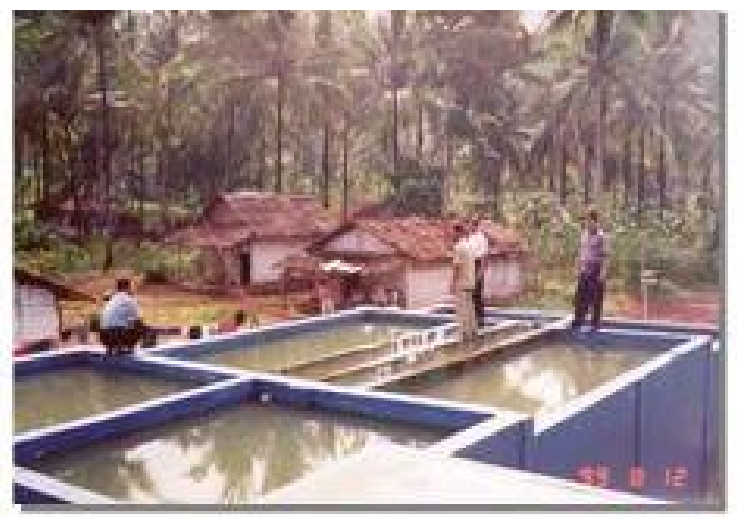

Figure 8. An example of slow sand filter of water purification reactor. 


\section{CONCLUSION}

Degradation and reduction of water resource has been continuing and getting worse as a function of time. The steps in solving this problem has often been done but the degradation is still going on with the higher rate. The water pollution has so far been occuring everywhere in the world including in Indonesia. Experiences of developed countries in dealing with water pollution abatement and treatment since industrial revolution of 150 years ago might be applied in Indonesia for combating pollutants in the water body so that the quality of Indonesian water could be improved.

Several regulations in water management and its pollution treatment have been made by the Government of Indonesia. The implementation however still need to be firmly enforced at all cost.

In terms of water pollution abatement, the first thing that needs to be understood is the source of the pollution, pollution materials, and characteritics and behaviour of the pollutants. From those informations the technical decision on what technology employed could then be chosen.

As explained that water pollution will affect to the human health directly and environment particularly water body. Many deseases associated with health condition of the people are related to the degree of water quality. Therefore, grouping of water quality is necessary. In Indonesia, there are 4 (four) different classes of water quality, namely Classes I, II, III and IV. This water quality grouping is intended to be used as a step in dealing with water conservation and determining water quality standard of different classes of water sources.

Monitoring and evaluation need to be conducted in order to have enough data in enforcing the regulations. All parties involved in water management need good coordination so that each activity in water conservation and treatment could be monitored effectively.

Finally, water monitoring, conservation and treatment technologies must be developed so that they will be technologically sound, economically feasible and socially acceptable. The Center of Environmental Technology BPPT, one of Government research institutes, has developed appropriate technologies in dealing with monitoring, conservation, and treatment of water pollution in the country.

\section{REFERENCES}

1. Bitton, G. 1994. Wastewater Microbiology, A John Wiley \& Sons, Inc., New York.

2. KelAir, 2005. "Kelompok Teknologi Pengelolaan Air Bersih dan Limbah Cair", P3TL-TIEML-BPPT.

3. Keputusan Menteri Negara Lingkungan Hidup No. Kep 51/MENLH/10/1995 tentang Baku Mutu Limbah Cair Bagi Kegiatan Industri.

4. Nathanson, J.A., Basic Environmental Technology - Water Supply, Waste Disposal, and Pollution Control, John Wiley and Sons, Inc., New York, 1986.

5. Nugroho, S.P., 2002, Pengelolaan DAS dan Sumberdaya Air yang Berkelanjutan, Peluang dan Tantangan Pengelolaan Sumberdaya Air di Indonesia.

6. O'Keefee, T.C, Elliott, S.R., Naiman, R. J. and Norton, D.J., 2007. "Introduction to Watershed Ecology". University of Washington and. USEPA Office of Water.

7. Peraturan Pemerintah Nomor 85 tahun 1999 tentang Pengelolaan Limbah Bahan Beracun Berbahaya.

8. Peraturan Pemerintah RI Nomor 16 Tahun 2005 tentang Pengembangan Sistem Penyediaan Air Minum.

9. Peraturan Pemerintah RI Nomor 82 Tahun 2001 tentang Pengelolaan Kualitas Air dan Pengendalian Pencemaran Air.

10. Peraturan Pemerintah nomor 19 Tahun 1994 tentang Pengelolaan Limbah Bahan Berbahaya dan Beracun.

11. Pitono, D. 2003, Sumbangan Brantas Untuk Pembangunan Berkelanjutan, disajikan dalam Seminar Sistem Monitoring Pencemaran Lingkungan Sungai dan Teknologi Pengelolaannya, Hotel Panghegar, Bandung, 8-9 Juli 2003, Penyelenggara PPET, LIPI.

12. Undang-undang Nomor 23 Tahun 1997 tentang Pengelolaan Lingkungan Hidup

13. Undang-undang Nomor 7 Tahun 2004 tentang Sumber Daya Air. 